\title{
Recent Changes in the Bioeconomic of Finfish Mariculture in Vietnam
}

Elizabeth H Petersen ${ }^{1 *}$, Brett D Glencross ${ }^{2}$, Nguyen Van Tien ${ }^{3}$, Le Anh Tuan ${ }^{4}$, Vu An Tuan ${ }^{5}$ and Truong Ha Phuong ${ }^{6}$

${ }^{1}$ University of Western Australia, 35 Stirling Highway, CRAWLEY WA 6009, Australia

${ }^{2}$ CSIRO Aquaculture, PO Box 2583, Brisbane, QLD 4001, Australia

${ }^{3}$ Research Institute for Aquaculture No 1, Dinh Bang, Tu Son, Bac Ninh, Vietnam

${ }^{4}$ Nha Trang University, 02 Nguyen Dinh Chieu, Vinh Tho, Nha Trang, Khanh Hoa, Vietnam

${ }^{5}$ Research Institute of Aquaculture No 2, 116 Nguyen Dinh Chieu, Ward 1, HCM City, Vietnam

${ }^{6}$ Research Institute for Aquaculture No 3, 33 Dang Tat, Nha Trang, Khanh Hoa, Vietnam

\begin{abstract}
Finfish mariculture farmers in Vietnam are making careful practice change decisions in reaction to a number of economic drivers. These economic drivers are centred on trends of increasing input costs and decreasing output prices. In general, mariculture farmers are adapting to the cost-price squeeze in a number of ways, including increasing stocking densities and area, and by adopting risk-reducing strategies (decreasing grow-out periods and using a larger number of smaller ponds to spread mortality risk). However, there is still a shortage of good quality low-cost fingerlings which is constraining farmers' ability to adapt to the cost-price squeeze. The dominant input cost source is feed. Most farmers are still reliant on trash-fish feeds. With low and decreasing feed conversion ratios for trash-fish, there is decreasing incentive for these farmers to change to pelleted diets. Southern Asian seabass farmers have made the practice change to pellets, but feed conversion ratios are high preventing significant economic gains from making the change. This research highlights two key areas where policy, research and extension initiatives can have a significant impact on the long-term economic and environmental viability of mariculture operations in Vietnam while protecting fish stocks: firstly, ensuring the widespread availability of low-cost hatchery-produced fingerlings, and secondly, encouraging practice change from trash-fish diets to the well-managed use of manufactured pelleted diets.
\end{abstract}

Keywords: Mariculture; Vietnam; Cobia; Grouper; Asian Seabass; Bioeconomics

\section{Introduction}

Fish production in Vietnam has experienced significant growth in the last decade. Imports are limited to raw material for aquaculture, with exports of fish and fish production up from USD1.5 billion in 2000 to USD5.1 billion in 2010, when it became the fourth-largest exporter of seafood in the world [1] (FAO 2013). In 2011, Vietnam's exports rose further to USD6.2 billion linked mainly to its flourishing aquaculture industry. Aquaculture production almost doubled between 2006 and 2012, from 1.7 million tonnes to 3.3 million tonnes, contributing $3-4 \%$ of global aquaculture production during this time period.

With rapidly increasing domestic demand, food security in Vietnam has benefited from aquaculture development of a number of diverse freshwater, brackish-water and marine-water species. Of specific interest to this study is the marine-water aquaculture species of cobia, grouper and Asian seabass. Global aquaculture production of these species has increased by $45-65 \%$ over the last five years, and is dominated by China (Table 1). Vietnam is the second largest aquaculture producer of cobia, with 9 percent of global production in 2012. It is a smaller player in terms of grouper and Asian seabass aquaculture production, with six and seven percent of global production, respectively.

Cobia, Rachycentron canadum, is a pelagic, coastal, migratory fish species distributed worldwide in tropical, subtropical and warmtemperate waters [2]. They are a luxury food fish in high demand by Asian consumers, especially in Taiwan and Japan. The belly is especially valued, having high lipid content, and is often served in restaurants as sashimi [3]. Due to the fast growth rate of cobia, high market value and success of mass seed production, it has become increasingly popular for cage culture in Southeast Asia. Cage culture is the rearing of cobia in enclosures, generally constructed of netting, supported by rigid frames in large bodies of water. In cages, cobia can grow to six kilograms within one year [4-7]. The first successful intensive mass production of cobia fingerlings in Vietnam was in 1999 [5,8]. The industry has

\begin{tabular}{|l|c|c|c|c|c|}
\hline & $\mathbf{2 0 0 8}$ & $\mathbf{2 0 0 9}$ & $\mathbf{2 0 1 0}$ & $\mathbf{2 0 1 1}$ & $\mathbf{2 0 1 2}$ \\
\hline Cobia & & & & & \\
\hline All countries & 26,400 & 33,400 & 40,900 & 42,400 & 43,800 \\
\hline Vietnam & 1,500 & 1,800 & 2,000 & 3,600 & 4,000 \\
\hline China (\%) & 90 & 87 & 89 & 91 & 91 \\
\hline Vietnam (\%) & 6 & 5 & 5 & 8 & 9 \\
\hline Grouper & & & & & \\
\hline All countries & 72,900 & 70,200 & 75,600 & 87,700 & 111,500 \\
\hline Vietnam & - & - & - & - & 6,500 \\
\hline China (\%) & 62 & 63 & 65 & 68 & 65 \\
\hline Vietnam (\%) & - & - & - & - & 6 \\
\hline Asian seabass & & & & & \\
\hline All countries & 139,300 & 151,100 & 173,000 & 191,900 & 201,200 \\
\hline Vietnam & - & - & - & - & 14,700 \\
\hline China (\%) & 69 & 68 & 61 & 64 & 63 \\
\hline Vietnam (\%) & - & - & - & - & 7 \\
\hline
\end{tabular}

FAO (2013), unpublished statistics from the Ministry of Agriculture and Rura Development, Vietnam.

- = data not collected

Table 1: Global aquaculture production of focus mariculture species (t/year unless specified otherwise)

*Corresponding author: Petersen EH, University of Western Australia, 35 Stirling Highway, CRAWLEY WA 6009, Australia, Tel: +61 89332 8310; E-mail: Liz.Petersen@tpg.com.au

Received November 07, 2014; Accepted December 29, 2014; Published January 31, 2015

Citation: Petersen EH, Glencross BD, Tien NV, Tuan LA, Tuan VA, et al. (2015) Recent Changes in the Bioeconomic of Finfish Mariculture in Vietnam. J Aquac Res Development 6: 311. doi:10.4172/2155-9546.1000311

Copyright: (C 2015 Petersen EH, et al. This is an open-access article distributed under the terms of the Creative Commons Attribution License, which permits unrestricted use, distribution, and reproduction in any medium, provided the original author and source are credited. 
expanded from protected areas into more exposed areas of the ocean with better water exchange [9]. Cobia is cultured in Vietnam by small to medium-scale family farms (approximately 1,000 tons/year, mostly for local consumption) as well as cooperative farms (approximately 1,600 tons/year, mostly for export) $[9,10]$.

Groupers, Serranidae Epinephelinae ${ }_{2}$ are the main species that farmers have chosen to replace shrimp culture [11]. The various grouper species commonly used in cage and pond culture are Epinephelus malabaricus (Malabar grouper), E. coioides (Orangespotted grouper), E. fuscoguttatus (Brown-marbled grouper), E. akaara (Red-spotted grouper), E. bleekeri (Duskytail grouper), E. sexfasciatus (Sixbar grouper), E. merra (Honeycomb grouper), Cephalopholis miniata (Coral Rockcod) and Plectropomus leopardus (Coral trout) [12]. Grouper production in Vietnam is not reported separately from marine finfish production in official government statistics, so it is difficult to estimate annual production. It is the domain of small-scale and family-operated businesses. It is primarily based on the use of wildcaught fry and fingerlings. Currently, fingerling are either caught from natural sources or imported from Taiwan, China or Indonesia. There are some hatcheries in Vietnam that can produce grouper fingerlings, but supply from this source is low (less than 1 million/year). Locally caught trash fish are the predominant feed source.

Asian seabass (or barramundi), Lates calcarifer, is a large predatory fish found in coastal, estuarine and freshwater environments in the Indo-Pacific region. It is well-established in the market place, where it is traded live to the Asian restaurant market and served at plate size (300$500 \mathrm{~g}$ whole or live) and as a fillet or large whole fish (approximately 2 $\mathrm{kg}$ ). Sea bass flesh has a reputation of having premium edible properties as it is tender, white, firm and mild-tasting with boneless fillets [13]. Asian seabass is a fast growing species making it a popular species for aquaculture. Techniques for its culture were developed in Thailand in the early 1970s. During the 80s and 90s, seabass aquaculture expanded to China, India, Indonesia, Malaysia, the Philippines, Singapore Taiwan, Vietnam and Australia [14].

Cobia, grouper and Asian sea bass are carnivorous and therefore require a high protein diet for efficient growth. Diets used for grow-out in Vietnam focus on trash-fish with feed conversion ratios (FCRs) of approximately 4 and higher. However, commercial diets are available from feed manufacturers and are generally produced as a floating or sinking pellet. FCRs for sea bass fed on pellets should range in 1.0-2.0 [14].

The main constraints faced by each of these mariculture species include reducing the dependence on wild-caught seed and feed, as well as constraints in the quantity and quality of seed supply. The importance of the widespread adoption of pellet feed and hatchery production of juveniles is highlighted by Sadovy and Lau [15]. The advantages of converting from trash-fish to pelleted feeds include fewer parasites and diseases, fewer environmental problems, more stable feed quality and improvements in water quality.

This paper aims to generate data on the bio-economics of mariculture, benchmark current feeding practices, and determine farmer perceptions about using pellets compared with trash-fish diets in grow-out marine fish aquaculture in Vietnam. One strategy in pursuit of this goal is the development of a series of bioeconomic models on cobia, grouper and Asian sea bass mariculture to identify the significant input factors contributing to economic performance, and to model the effects of various feeding strategies on profitability. Household surveys of mariculture farmers were conducted in 2010, which provided the data used to generate the original bioeconomic models for each of these species as produced in various growout regions in Vietnam. The resulting bioeconomic analyses were reported as Petersen et al. [16-18]. As a follow-up to this original study, in 2013, the household surveys were repeated to compare trends in the bioeconomics of these three focus species through time. The primary purpose of this paper therefore is to present this comparison.

\section{Methodology}

Bioeconomic modelling is a widely used tool for analysing the possible effects of technology change and policy intervention on the quality of natural resources use and household welfare. It is favoured as a tool of analysis due to its ability to closely integrate important biophysical processes with economic decision behaviour. Examples of the use of bioeconomic modelling in fishery/aquaculture management applications include [19-25].

This paper reports on the outcomes of twelve bioeconomic models populated from household surveys of across Vietnam. The surveys included developing, pilot-testing, revising, and administering a 47-question comprehensive questionnaire face-to-face with smallscale farming households in mid-2010 and mid-2013. The respondents were randomly selected and surveyed by Vietnamese co-authors from the Research Institute for Aquaculture No 1 (northern farmers), the Research Institute for Aquaculture No 3 (central farmers), the Nha Trang University (central farmers) and the Research Institute for Aquaculture No 2 (southern farmers). Six models were developed and populated with 2010 data; cobia north and cobia south (documented in Petersen et al. [18]), grouper north and grouper central (documented in Petersen et al. [17]), and seabass centre and seabass south (documented in Petersen et al. [16]). The data in each of these six models was revised with 2013 data, and results of the two years of data are compared in this paper.

The data presented are grouped and averaged. Readers are invited to contact the authors for a copy of the questionnaire. Survey location and sample size is provided in Table 2. Overall, 90 questionnaires were administered across five provinces in 2010 and a further 144 in eight provinces in 2013.

\begin{tabular}{|c|c|c|c|c|c|c|}
\hline & \multicolumn{2}{|c|}{ Cobia } & \multicolumn{2}{|c|}{ Grouper } & \multicolumn{2}{|c|}{ Asian seabass } \\
\hline & Province & $\begin{array}{l}\text { Sample } \\
\text { size }\end{array}$ & Province & $\begin{array}{c}\text { Sample } \\
\text { size }\end{array}$ & Province & $\begin{array}{c}\text { Sample } \\
\text { size }\end{array}$ \\
\hline \multicolumn{7}{|c|}{2010} \\
\hline North & Hai Phong & 28 & Hai Phong & 21 & - & - \\
\hline Central & - & - & $\begin{array}{c}\text { Khanh Hoa } \\
\text { Phu Yen }\end{array}$ & 16 & $\begin{array}{c}\text { Khanh } \\
\text { Hoa }\end{array}$ & 4 \\
\hline South & $\begin{array}{c}\text { Ba Ria } \\
\text { Vung Tau }\end{array}$ & 13 & - & - & $\begin{array}{c}\text { Ba Ria } \\
\text { Vung Tau }\end{array}$ & 8 \\
\hline Total & & 41 & & 37 & & 12 \\
\hline TOTAL & & & & & & 90 \\
\hline \multicolumn{7}{|c|}{2013} \\
\hline North & $\begin{array}{l}\text { Hai Phong } \\
\text { Quang Ninh }\end{array}$ & 20 & $\begin{array}{c}\text { Hai Phong } \\
\text { Quang } \\
\text { Ninh }\end{array}$ & 20 & - & - \\
\hline Central & - & - & $\begin{array}{c}\text { Khanh Hoa } \\
\text { Phu Yen }\end{array}$ & 40 & $\begin{array}{c}\text { Khanh } \\
\text { Hoa } \\
\text { Phu Yen }\end{array}$ & 20 \\
\hline South & $\begin{array}{l}\text { Kien Giang } \\
\text { Vung Tau }\end{array}$ & 25 & - & - & $\begin{array}{l}\text { Bac Lieu } \\
\text { Soc Trang }\end{array}$ & 19 \\
\hline Total & & 45 & & 60 & & 39 \\
\hline TOTAL & & & & & & 144 \\
\hline
\end{tabular}

Table 2: Location and sample size for 2010 and 2013 household surveys. 
Each of the bioeconomic models follow the same methodology which is described below in two sub-sections. The biological component is described in the biological component of the bioeconomic models, and the economics component is described in The economic component of the bioeconomic model.

\section{The biological component of the bioeconomic models}

The biological component assumes that the mariculture species do not gain significant nutrition from their imposed environment and would not survive in the absence of supplementary feeding. The individual fish biomass at harvest $\left(b_{H}\right)$ is taken from the survey data. Farmers use four different growth phases to vary the stocking rate (using different sized cages or ponds) and feeding regime (details of which are presented in the results section). The biological model measures biomass gain from each of these phases, $w_{i}$, multiplied by the total number of surviving fish at the end of each growth phase, $N_{i}$. This is summed across each phase to measure total biomass gain at harvest $\left(W_{H}\right)$ as per equation (1):

$$
W_{H}=\sum_{i=1}^{4}\left(N_{i} * w_{i}\right)
$$

Biomass gain in each phase is measured by dividing the quantity of feed during growth phase, $q_{F i}$, with the feed conversion ratio, $F C R_{i}$ (wet weight) of the feed during growth phase, $i$, as per equation (2):

$$
\mathrm{w}_{\mathrm{i}}=\mathrm{q}_{\mathrm{Fi}} / \mathrm{FCR}_{\mathrm{i}}
$$

As the fish grow (between stocking and harvest), the stocking density, feed quantity, and quality are varied. This methodology allows for the analysis of different feeding regimes (feeding different quantities of feeds with different FCRs and feed prices) on fish growth, up to a maximum harvest size.

\section{The economic component of the bioeconomic model}

The annual enterprise gross margin is a simple net revenue function as shown in equation (3):

\section{$N R=T R-T C$}

where: $N R=$ annualized net revenue (USD);

$T R=$ annualized total revenue (USD); and

$T C=$ annualized total costs (USD).

Total revenue is a function of the total weight of production and price as shown in equation (4):

$$
T R=W_{H}^{*} P_{H}
$$

where: $W_{H}=$ total weight of production (kilograms, $\mathrm{kg}$ ) (see equation (2); and

\section{$P_{H}=$ the farm-gate price of the harvested fish.}

Total costs are a function of restocking costs and a number of miscellaneous fixed and variable costs as shown in equation (5):

$$
T C=\Sigma C_{S i}+\sum C_{F i}+C_{L}+\sum C_{C P i}+C_{O}+C_{I}+C_{M}
$$

where: $T C=$ total costs (USD/year);

$C_{S i}=$ seed costs at grow-out phase $i=1$ (USD/year);

$C_{F i}=$ feed costs at grow-out phase $i=1$ to 4 (USD/year);

$C_{L}=$ labor costs (USD/year) (costed as half the opportunity cost of off-farm labor alternatives);
$C_{C P_{i}}=$ cage or pond purchase, establishment or maintenance costs at grow-out phase $i=1$ to 4 (USD/year);

$$
C_{O}=\text { other capital costs (USD/year); }
$$

$C_{I}=$ interest costs (USD/year); and

$C_{M}=$ contingency costs for miscellaneous purchases (USD/year).

The fixed costs include labor, cage/pond, other, and contingency costs. All other costs are variable.

Annual seed costs, $C_{S}$, are a function of stocking and cage/pond parameters as shown in equation (6):

$$
C_{S i}=S R_{i}{ }^{*} S_{C P i}{ }^{*} N_{C P i}{ }^{*} P_{S}^{*} N
$$

where: $S R_{i}=$ stocking rate at grow-out phase $i=1$ (individuals $/ \mathrm{m}^{3}$ );

$S_{C P i}=$ average size of nursery cages or ponds at grow-out phase $i=1$ $\left(\mathrm{m}^{3} /\right.$ cage $)$ or $\left(\mathrm{m}^{3} /\right.$ pond $)$;

$N_{C P}=$ number of cages or ponds at grow-out phase $i=1$;

$P_{S}=$ price of seed (USD/individual); and

$N=$ number of crops (grow-out) cycles per year.

Annual feed costs are a function of the quantity and price of feed for each growth phase as shown in equation (7):

$$
C_{F}=\sum_{i=1}^{4} Q_{F i} * P_{F i} * N
$$

where: =quantity of feed at growth phase, $i=1$ to $4(\mathrm{~kg} / \mathrm{phase})$; and

$P_{F i}=$ price of feed at growth phase, $i=1$ to 4 .

The annual enterprise gross margin, cage, pond and other capital costs are annualized by dividing the costs by the number of years to replacement.

\section{Results}

This description of recent changes in the bioeconomics of smallscale mariculture farming in Vietnam focuses on the difference in household survey results for cobia, grouper and Asian seabass between 2010 and 2013. It is presented in two parts. A description of the data used in the biological models (husbandry, biological and economic information) is provided in the first part (Description of the recent changes in the bioeconomics of small-scale mariculture farming in Vietnam). The results of the bioeconomic model are provided in the second part (Bioeconomic analysis). Monetary values are provided in nominal United States Dollars (USD) which, at the time of data collection, had an exchange rate of $1 \mathrm{USD}=19,400$ Vietnamese Dong in 2010 and 1 USD=21,237 Vietnamese Dong in 2013.

Description of the recent changes in the bioeconomics of small-scale mariculture farming in Vietnam

Mariculture growout of the three focus species is practiced as a monoculture by all surveyed households, with either a crop every year or every two years, with no change to these operations over the three years studied (Table 3). Generally, the price of fingerlings has increased significantly (by between 27 and 205 percent) for cobia and Asian seabass farmers, whereas the price of seed has decreased (or increased modestly) for grouper farmers. This correlates with a trend towards using larger fingerlings by cobia and Asian seabass farmers, and smaller fingerlings by grouper farmers. It is unclear whether grouper farmers are choosing to use smaller fingerlings, or are constrained to do so due 
Citation: Petersen EH, Glencross BD, Tien NV, Tuan LA, Tuan VA, et al. (2015) Recent Changes in the Bioeconomic of Finfish Mariculture in Vietnam. J Aquac Res Development 6: 311. doi:10.4172/2155-9546.1000311

Page 4 of 9

\begin{tabular}{|c|c|c|c|c|c|c|c|c|c|c|c|c|c|c|}
\hline & \multicolumn{4}{|c|}{ Cobia } & \multicolumn{6}{|c|}{ Grouper } & \multicolumn{4}{|c|}{ Seabass } \\
\hline & \multicolumn{2}{|c|}{ North } & \multicolumn{2}{|c|}{ South } & \multicolumn{2}{|c|}{ North } & \multicolumn{4}{|c|}{ Central } & \multicolumn{2}{|c|}{ Central } & \multicolumn{2}{|c|}{ South } \\
\hline & 2010 & 2013 & 2010 & 2013 & 2010 & 2013 & 2010 & 2013 & 2010 & 2013 & 2010 & 2013 & 2010 & 2013 \\
\hline Cage or pond & \multicolumn{4}{|c|}{ cage } & \multicolumn{4}{|c|}{ cage } & \multicolumn{2}{|c|}{ pond } & \multicolumn{2}{|c|}{ pond } & cage & pond $^{\mathrm{b}}$ \\
\hline Average number of crops per year & $0.5^{\mathrm{a}}$ & $0.5^{\mathrm{a}}$ & 1.0 & 1.0 & 0.5 & 0.5 & 1.0 & 1.0 & 1.0 & 1.0 & 1.0 & 1.0 & 1.0 & 1.0 \\
\hline Price of seed fingerlings (USD/fingerling) & 0.60 & 0.97 & 0.95 & 2.9 & 2.0 & 1.9 & 1.1 & 0.90 & 0.79 & 1.0 & 0.14 & 0.14 & 0.13 & 0.22 \\
\hline Length of fingerlings (cm/fingerling) & 10 & 15 & 11 & 16 & 16 & 8 & 11 & 9.6 & 7.8 & 6.5 & 1.6 & 4.5 & 4.3 & 7.8 \\
\hline Stocking density $\left(\mathrm{fish} / \mathrm{m}^{3}\right)$ & 9.3 & 7.4 & 13 & 7.0 & 12 & 6.0 & 19 & 57 & 0.5 & 1.1 & 1.0 & 1.3 & 16 & 2.2 \\
\hline Number of fish stocked & 1,300 & 1,900 & 2,400 & 1,200 & 2,200 & 1,400 & 1,200 & 1,900 & 4,500 & 13,000 & 9,000 & 15,000 & 4,200 & 12,000 \\
\hline Survival (\%) & 50 & 53 & 87 & 83 & 48 & 35 & 77 & 56 & 59 & 56 & 56 & 73 & 72 & 43 \\
\hline
\end{tabular}

aWhile the grow-out period for cobia in the north is 18-19 months per year, there is a delay between harvest and seeding. Farmer's produce one crop every two years.

${ }^{b}$ Due to a significant reduction in the harvest price for seabass, southern cage farmers have moved away from seabass to other species. Hence, the survey was based on pond farming of Asian Seabass.

Table 3: Seed, stocking and survival information.

\begin{tabular}{|c|c|c|c|c|c|c|c|c|c|c|c|c|c|c|}
\hline & \multicolumn{4}{|c|}{ Cobia } & \multicolumn{6}{|c|}{ Grouper } & \multicolumn{4}{|c|}{ Asian seabass } \\
\hline & \multicolumn{2}{|c|}{ North } & \multicolumn{2}{|c|}{ South } & \multicolumn{2}{|c|}{ North } & \multicolumn{4}{|c|}{ Central } & \multicolumn{2}{|c|}{ Central } & \multicolumn{2}{|c|}{ South } \\
\hline & 2010 & 2013 & 2010 & 2013 & 2010 & 2013 & 2010 & 2013 & 2010 & 2013 & 2010 & 2013 & 2010 & 2013 \\
\hline Cage or pond & \multicolumn{4}{|c|}{ cage } & \multicolumn{4}{|c|}{ cage } & \multicolumn{2}{|c|}{ pond } & \multicolumn{2}{|c|}{ pond } & cage & pond \\
\hline Length of grow-out cycle (months) & 19 & 18 & 10 & 10 & 23 & 24 & 14 & 11 & 14 & 11 & 11 & 8.6 & 11 & 9.5 \\
\hline Weight at harvest (kg) & 4.2 & 5.1 & 5.9 & 5.3 & 3.2 & 2.5 & 0.93 & 1.0 & 0.97 & 1.0 & 1.0 & 1.0 & 1.0 & 0.78 \\
\hline Total harvest biomass (kg) & 2,700 & 5,000 & 12,000 & 5,600 & 3,300 & 1,200 & 870 & 1,100 & 2,600 & 7,300 & 5,000 & 11,000 & 3,000 & 4,000 \\
\hline Harvest price (USD/kg) & 4.7 & 3.8 & 3.7 & 5.2 & 12 & 8.3 & 9.1 & 9.3 & 9.1 & 9.3 & 3.0 & 2.4 & 3.5 & 2.7 \\
\hline
\end{tabular}

Table 4: Harvest information.

\begin{tabular}{|c|c|c|c|c|c|c|c|c|c|}
\hline & \multicolumn{4}{|c|}{ Cobia } & \multicolumn{4}{|c|}{ Grouper } & \multirow{3}{*}{$\begin{array}{c}\text { Asian seabass } \\
\text { South } \\
2010\end{array}$} \\
\hline & \multicolumn{2}{|c|}{ North } & \multicolumn{2}{|c|}{ South } & \multicolumn{2}{|c|}{ North } & \multicolumn{2}{|c|}{ Central } & \\
\hline & 2010 & 2013 & 2010 & 2013 & 2010 & 2013 & 2010 & 2013 & \\
\hline Average number of cages per householda & 6 & $5-8$ & $2-15$ & $2-9$ & $7-8$ & $4-5$ & 5 & $4-14$ & 3 \\
\hline Average size of cage $\left(\mathrm{m}^{3}\right)$ & 27 & 63 & 92 & 110 & 27 & 59 & 13 & 17 & 79 \\
\hline Average cost of cage purchase (USD/cage) & 250 & 190 & 450 & 720 & 220 & 190 & 140 & 930 & 490 \\
\hline Average time to replacement (years) & 13 & 6.8 & 7.9 & 6.0 & 11 & 7.0 & 6.0 & 6.0 & 8.0 \\
\hline
\end{tabular}

avariation indicates changes in number of cages between nursery and final grow-out phase.

Table 5: Cage information.

\begin{tabular}{|l|c|c|c|c|c|c|}
\hline & \multicolumn{3}{|c|}{ Grouper } & \multicolumn{3}{c|}{ Asian seabass } \\
\hline & \multicolumn{2}{|c|}{ Central } & \multicolumn{2}{c|}{ Central } & South \\
\hline & 2010 & 2013 & 2010 & 2013 & 2013 \\
\hline Average number of ponds per household & 2.0 & 2.6 & 1.0 & 1.5 & 1.2 \\
\hline Average individual pond surface area $\left(\mathrm{m}^{2}\right)$ & 3,500 & 3,400 & 6,800 & 4,200 & 3,300 \\
\hline Average individual depth $(\mathrm{m})$ & 1.3 & 1.4 & 1.4 & 1.2 & 1.4 \\
\hline Average individual pond size $\left(\mathrm{m}^{3}\right)$ & 5,700 & 4,900 & 9,500 & 5,000 & 4,800 \\
\hline Average total pond culture area $\left(\mathrm{m}^{3}\right)$ & 11,000 & 12,000 & 9,500 & 7,600 & 5,500 \\
\hline $\begin{array}{l}\text { Annual pond prep and maintenance }(\mathrm{USD} / \\
\text { crop) }\end{array}$ & 220 & 380 & 260 & 83 & 198 \\
\hline
\end{tabular}

Table 6: Pond information.

to the availability of smaller fingerlings. Generally, the use of larger fingerlings by cobia and Asian seabass farmers has led to significantly lower average stocking densities (20-100\% lower), and higher stocking densities by grouper farmers (120-200\% higher). Survival rates are mixed, although significantly lower survival rates have been experienced in grouper cage culture, perhaps due to the reduced size (and perhaps quality) of fingerlings.

The average length of the growout cycle is largely unchanged from three-years prior for cobia farmers. The growout length has decreased for grouper culture in the centre region with a marginal increase in weight at harvest, and seabass culture with a decrease in size in the south (Table 4).

Average total harvest biomass has increased for most farming systems, mostly due to a larger number of fish stocked (although higher harvest weight and/or survival rate has an influence in some cases). On average, southern cobia farmers and northern grouper farmers have experienced a decrease in total harvest biomass, due to a reduction in the number of fish stocked (largely due to increases in fingerling prices), individual fish weight at harvest and survival (due to disease).

Most farmers have experienced a reduction in the farm-gate price for their produce over the last three years, in the order of $20-30 \%$. Grouper farmers in the north and south have experienced a marginal increase in price. Only cobia farmers in the south have experienced significant increases in the farm-gate price of their produce (by $40 \%$ ). Though not documented in a table in this paper, farmers perceive that the farm-gate price of their produce has been increasing over time by 14- $94 \%$ (with the exception of central Asian seabass farmers), but that the price has made a slight decrease in the last year by $3-30 \%$.

Information about the use of cages and ponds is presented in Tables 5 and 6. With the exception of these southern Asian seabass farmers, the average size of cages has increased over the three year period. The cost of cages in the north has decreased marginally, while the cost of cages in the south has increased significantly. The average time to cage replacement has generally fallen over the time period. With regard to pond farming, the average number of ponds per household has increased, but the average size of ponds has decreased. The cost of pond preparation and maintenance has increased for grouper farmers but decreased for seabass farmers. 
Citation: Petersen EH, Glencross BD, Tien NV, Tuan LA, Tuan VA, et al. (2015) Recent Changes in the Bioeconomic of Finfish Mariculture in Vietnam. J Aquac Res Development 6: 311. doi:10.4172/2155-9546.1000311

Page 5 of 9

\begin{tabular}{|c|c|c|c|c|c|c|c|c|c|c|c|c|c|c|}
\hline & \multicolumn{4}{|c|}{ Cobia } & \multicolumn{6}{|c|}{ Grouper } & \multicolumn{4}{|c|}{ Asian seabass } \\
\hline & \multicolumn{2}{|c|}{ North } & \multicolumn{2}{|c|}{ South } & \multicolumn{2}{|c|}{ North } & \multicolumn{4}{|c|}{ Central } & \multicolumn{2}{|c|}{ Central } & \multicolumn{2}{|c|}{ South } \\
\hline & 2010 & 2013 & 2010 & 2013 & 2010 & 2013 & 2010 & 2013 & 2010 & 2013 & 2010 & 2013 & 2010 & 2013 \\
\hline Cage or pond & \multicolumn{4}{|c|}{ cage } & \multicolumn{4}{|c|}{ cage } & \multicolumn{2}{|c|}{ pond } & \multicolumn{2}{|c|}{ pond } & cage & pond \\
\hline Aerator (\% of hhds) & 0 & 0 & 100 & 0 & 0 & 0 & 0 & 0 & 25 & 0 & 25 & 0 & 63 & 58 \\
\hline - Number & - & - & 1.0 & - & - & - & - & - & 2.0 & - & 2.0 & - & 1.2 & 2.5 \\
\hline - Annual replacement cost (USD/yr) & - & - & 32 & - & - & - & - & - & 130 & - & 0.50 & - & 0.44 & 25 \\
\hline Boats (\% of hhds) & 46 & 50 & 100 & 88 & 23 & 65 & 63 & 0 & 13 & 15 & 0 & 35 & 88 & 37 \\
\hline - Number & 1.9 & 1.0 & 1.4 & 1.1 & 2.1 & 1.0 & 1.0 & - & 1.0 & 1.0 & - & 1.0 & 1.0 & 1.6 \\
\hline - Annual replacement cost (USD/yr) & 1,200 & 56 & 72 & 43 & 960 & 55 & 6.7 & - & 42 & 6.7 & - & 14 & 26 & 33 \\
\hline Frame (\% of hhds) & 0 & 0 & 46 & 0 & 0 & 0 & 0 & 0 & 88 & 0 & 50 & 75 & 75 & 0 \\
\hline - Number & - & - & 6.0 & - & - & - & - & - & 3.1 & - & 2.0 & 1.7 & 3.7 & - \\
\hline - Annual replacement cost (USD/yr) & - & - & 35 & - & - & - & - & - & 31 & - & 14 & 7.0 & 0.74 & - \\
\hline Light (\% of hhds) & 0 & 95 & 100 & 80 & 14 & 95 & 100 & 59 & 38 & 62 & 25 & 5.0 & 88 & 58 \\
\hline - Number & - & 2.2 & 3.6 & 8.6 & 2.3 & 22 & 2.0 & 1.9 & 4.7 & 1.4 & 2.0 & 2.0 & 3.3 & 4.5 \\
\hline - Annual replacement cost (USD/yr) & - & 3.9 & 11 & 2.2 & 17 & 8.0 & 5.2 & 15 & 15 & 15 & 0.10 & 2.0 & 0.067 & 8.3 \\
\hline Nets $(\%$ of hhds) & 0 & 100 & 31 & 56 & 0 & 100 & 25 & 63 & 0 & 0 & 0 & 10 & 0 & 53 \\
\hline - Number & - & 8.5 & 1 & 4.9 & - & 4.7 & 1.0 & 6.5 & - & - & - & 1.0 & - & 1.2 \\
\hline - Annual replacement cost (USD/yr) & - & 2.6 & 17 & 38 & - & 2.7 & 30 & 66 & - & - & - & 24 & - & 42 \\
\hline Pump (\% of hhds) & 0 & 0 & 100 & 48 & 0 & 0 & 0 & 0 & 75 & 68 & 25 & 25 & 88 & 100 \\
\hline - Number & - & - & 1.0 & 1.30 & - & - & - & - & 1.8 & 1.2 & 1.0 & 1.0 & 1.0 & 1.4 \\
\hline - Annual replacement cost (USD/yr) & - & - & 61 & 63 & - & - & - & - & 120 & 46 & 2.5 & 58 & 1.1 & 63 \\
\hline Tool (\% of hhds) & 0 & 0 & 38 & 40 & 0 & 0 & 0 & 11 & 0 & 53 & 0 & 60 & 0 & 0 \\
\hline - Number & - & - & n.a. & n.a. & - & - & - & n.a. & - & n.a. & - & - & - & - \\
\hline - Annual replacement cost (USD/yr) & - & - & 20 & 5.5 & - & - & - & 36 & - & 55 & - & 13 & - & - \\
\hline Paddle-wheel (\% of hhds) & 0 & 0 & 0 & 0 & 0 & 0 & 0 & 0 & 75 & 85 & 100 & 100 & 0 & 100 \\
\hline - Number & - & - & - & - & - & - & - & - & 1.8 & 2.0 & 2.0 & 3.1 & - & 3 \\
\hline - Annual replacement cost (USD/yr) & - & - & - & - & - & - & - & - & 120 & 67 & 120 & 80 & - & 42 \\
\hline
\end{tabular}

${ }^{a}$ Annual replacement cost is the cost per item divided by the time to replacement.

- = data not collected

Table 7: Equipment requirements.

\begin{tabular}{|c|c|c|c|c|c|c|c|c|c|c|c|c|c|c|}
\hline & \multicolumn{4}{|c|}{ Cobia } & \multicolumn{6}{|c|}{ Grouper } & \multicolumn{4}{|c|}{ Asian seabass } \\
\hline & \multicolumn{2}{|c|}{ North } & \multicolumn{2}{|c|}{ South } & \multicolumn{2}{|c|}{ North } & \multicolumn{4}{|c|}{ Central } & \multicolumn{2}{|c|}{ Central } & \multicolumn{2}{|c|}{ South } \\
\hline & 2010 & 2013 & 2010 & 2013 & 2010 & 2013 & 2010 & 2013 & 2010 & 2013 & 2010 & 2013 & 2010 & 2013 \\
\hline Cage or pond & \multicolumn{4}{|c|}{ cage } & \multicolumn{4}{|c|}{ cage } & \multicolumn{2}{|c|}{ pond } & \multicolumn{2}{|c|}{ pond } & cage & pond \\
\hline \multicolumn{15}{|c|}{ Nursery phase } \\
\hline Trash-fish & 12 & 2.7 & 12 & 1.3 & 8.1 & 1.4 & - & 4.0 & 6.0 & 2.3 & 1.9 & 1.1 & 3.6 & - \\
\hline Pellets & - & - & - & - & - & - & - & - & - & - & - & - & & 0.61 \\
\hline \multicolumn{15}{|c|}{ Grow-out phase 1} \\
\hline Trash-fish & 18 & 13 & 15 & 6.2 & 15 & 6.2 & 5.8 & 10 & 11 & 9.2 & 4.0 & 8.8 & 6.6 & - \\
\hline Pellets & - & - & - & - & - & - & - & - & - & - & - & - & - & 1.7 \\
\hline \multicolumn{15}{|c|}{ Grow-out phase 2} \\
\hline Trash-fish & 22 & 26 & 19 & 13 & 17 & 16 & 18 & 16 & 19 & 25 & 6.9 & 23 & 10 & - \\
\hline Pellets & - & - & - & - & - & - & - & - & - & - & - & - & - & 3.1 \\
\hline \multicolumn{15}{|c|}{ Grow-out phase 3} \\
\hline Trash-fish & 32 & 52 & 21 & 25 & 26 & 48 & 32 & 27 & 24 & 46 & 7.0 & 46 & 14 & - \\
\hline Pellets & - & - & - & - & - & - & - & - & - & - & - & - & - & 4.0 \\
\hline \multicolumn{15}{|c|}{ Average feed conversion ratio (FCR) } \\
\hline Trash-fish & 6.6 & 5.4 & 6.4 & 5.0 & 9.1 & 4.2 & 12 & 12 & 12 & 13 & 6.2 & 5.9 & 4.0 & - \\
\hline Pellets & - & - & - & - & - & - & - & - & - & - & - & - & - & 2.0 \\
\hline
\end{tabular}

- = data not collected

Table 8: Approximate quantity of feed used (g/fish/day).

Information regarding changes in equipment used over the study period shows decreased use of aerators and frames, and increased use of nets (Table 7). The most expensive cost item for most farmers is a boat (although it depends whether the boat is motorised). The annual replacement value of boats has decreased for most farmers. Pumps and paddle-wheels are other expensive items. There are mixed trends in the replacement cost of these items over time.
Most farmers still rely on wild-caught trash-fish for feed (Table 8). While some cobia farmers use pellets in the nursery stage of growout, these are a minority (12-38\%) and are not an increasing trend between surveys. The exception is southern seabass farmers who have moved from a mixture of trash-fish to a predominately pelleted diet. Generally, over the last three years the approximate quantity of feed fed has decreased in the nursery phase and increased in the final grow-out 


\begin{tabular}{|c|c|c|c|c|c|c|c|c|c|c|c|c|c|c|}
\hline & \multicolumn{4}{|c|}{ Cobia } & \multicolumn{6}{|c|}{ Grouper } & \multicolumn{4}{|c|}{ Seabass } \\
\hline & \multicolumn{2}{|c|}{ North } & \multicolumn{2}{|c|}{ South } & \multicolumn{2}{|c|}{ North } & \multicolumn{4}{|c|}{ Central } & \multicolumn{2}{|c|}{ Central } & \multicolumn{2}{|c|}{ South } \\
\hline & 2010 & 2013 & 2010 & 2013 & 2010 & 2013 & 2010 & 2013 & 2010 & 2013 & 2010 & 2013 & 2010 & 2013 \\
\hline Average price of trash-fish (USD/kg) & 0.30 & 0.36 & 0.35 & 0.38 & 0.38 & 0.36 & 0.44 & 0.47 & 0.38 & 0.55 & 0.32 & 0.46 & 0.37 & - \\
\hline Average price of pellets (USD/kg) & - & - & - & - & - & - & - & - & - & - & - & - & & 1.30 \\
\hline
\end{tabular}

- = data not collected

Table 9: Price of feed.

\begin{tabular}{|c|c|c|c|c|c|c|c|c|c|c|c|c|c|c|}
\hline & \multicolumn{4}{|c|}{ Cobia } & \multicolumn{6}{|c|}{ Grouper } & \multicolumn{4}{|c|}{ Asian seabass } \\
\hline & \multicolumn{2}{|c|}{ North } & \multicolumn{2}{|c|}{ South } & \multicolumn{2}{|c|}{ North } & \multicolumn{4}{|c|}{ Central } & \multicolumn{2}{|c|}{ Central } & \multicolumn{2}{|c|}{ South } \\
\hline & 2010 & 2013 & 2010 & 2013 & 2010 & 2013 & 2010 & 2013 & 2010 & 2013 & 2010 & 2013 & 2010 & 2013 \\
\hline \multirow{2}{*}{$\begin{array}{l}\text { Cage or pond } \\
\text { Household (hhd) labour }\end{array}$} & \multicolumn{4}{|c|}{ cage } & \multicolumn{4}{|c|}{ cage } & \multicolumn{2}{|c|}{ pond } & \multicolumn{2}{|c|}{ pond } & cage & pond \\
\hline & \multicolumn{14}{|c|}{ Household (hhd) labour } \\
\hline $\begin{array}{l}\text { Average number of hhd members working on the } \\
\text { operation }\end{array}$ & 4.0 & 2.5 & 2.0 & 1.7 & 2.8 & 2.6 & 1.5 & 2.0 & 1.0 & 1.8 & 1.3 & 1.9 & 1.5 & 1.2 \\
\hline$\%$ of these hhd members that are male & 38 & 61 & 94 & 81 & 56 & 63 & 100 & 93 & 100 & 96 & 100 & 86 & 75 & 97 \\
\hline $\begin{array}{l}\text { Total number of days worked per week (for all hhd } \\
\text { members) }\end{array}$ & 22 & 13 & 14 & 13 & 19 & 14 & 11 & 9.3 & 7 & 8.8 & 8.9 & 11 & 7.9 & 7.6 \\
\hline \multicolumn{15}{|l|}{ Hired labour } \\
\hline Percentage of operations that employ hired labor & 14 & 0 & 69 & 16 & 29 & 0 & 0 & 0 & 62 & 15 & 50 & 5.0 & 75 & 21 \\
\hline Average number of hired workers & 4.5 & - & 2 & 2.8 & 2 & - & - & - & 1 & 1.5 & 1.0 & 2 & 1.8 & 1.8 \\
\hline $\begin{array}{l}\text { Total number of days worked per week (for all } \\
\text { hired workers) }\end{array}$ & - & - & 14 & 22 & - & - & - & - & - & 8 & 7.0 & 14 & 12 & 12 \\
\hline Cost of hired personnel (USD/worker/month) & 130 & - & 110 & 180 & 120 & - & - & - & 98 & 110 & 77 & 170 & 93 & 170 \\
\hline
\end{tabular}

- =data not collected, hhd=household

Table 10: Labor requirements.

phase, with mixed trends in the middle phases. Feed conversion ratios (FCRs) have generally decreased over time indicating that farmers are becoming more efficient with the way they feed their fish, ensuring less wastage. However, the survey questions relating to the quantity of feed used was the most difficult question for most farmers to answer. Hence, there is significant uncertainty regarding the quantity of feed used, and therefore the calculated FCRs.

The price of finfish has increased in all regions of Vietnam over the last three years by an average of $25 \%$ (Table 9). Unreported survey results indicate that the cost of pellets has increased by $250 \%$ over the study period, and that there is a trend of moving away from retailers to wholesalers as the main provider of trash-fish and pellets. The exception to this is finfish bought in the north by grouper farmers who have moved from almost exclusive wholesale purchases to exclusive retail purchases.

The survey questionnaire included a number of questions regarding farmer perceptions about the adaptability, cost and growth rates achieved by manufactured feeds (pellets). Farmers increasingly perceive that fish are adaptable to manufactured diets (the uncertainty farmers had previously felt regarding this has decreased). There was mixed perceptions regarding the relative cost of trash-fish and manufactured diets. No farmers expressed a perception that manufactured diets would lead to faster growth rates. Farmers increasingly perceived that pelleted diets are readily available to them, however, the proportion of households who indicated they would use pelleted diets has decreased (with increasing uncertainty regarding this).

Southern and northern farmers have decreased the average number of household members working on their operations, whereas central farmers have increased their number of household workers (Table 10). However, the number of days worked per week for farmers in all regions has decreased in time. Fewer farmers are hiring labour in all regions and for all focus species, which is likely due to the increased in the cost of labour (which increases by an average of $70 \%$ over the three-year study period).

The change in the proportion of households that use credit to finance part of their operations and the amount that they borrow, is mixed across regions and mariculture species, with no obvious trend (Table 11). Neither is there an obvious trend in the changing providers of credit. However, generally interest rates have increased from an average of $1.0 \% /$ month to $1.3 \% /$ month.

\section{Bioeconomic analysis}

The changes in the bioeconomics of cobia, grouper and Asian seabass growout mariculture from 2010 to 2013 is provided in this section. In general, the average harvest biomass has increased for most farming systems and farm-gate price has decreased (Table 12). However, harvest biomass has increased by a greater extent than price, and is the dominant influence on total revenue, which has increased for most farmers. Two exceptions to this are southern cobia and northern grouper farmers, where total biomass and therefore total revenue has decreased. In both cases this is due to fewer fish stocked.

Change in total harvest biomass is also the dominant influence on total costs, where the higher the biomass the higher the total costs. However, total costs per unit of production have increased over time for all farming systems except northern cobia systems. This increase in total costs per unit production is the result of increases in seed and feed costs. The dominant cost source for most operations is feed, which in 2013 averaged 56\% of total costs across all species and regions. While the cost of feed increased in all regions over the study period, the efficiency with which the feed was used (FCR) improved and the change in quantity of feed used was mixed. This resulted in mixed impacts on the percentage of feed costs in total costs. Labour and seed are the second largest cost sources, averaging $21 \%$ and $12 \%$ of total costs across all species and regions, respectively. Labour costs decreased and seed costs increased as a percentage of total costs over the time period. Although interest rates increased over the time period, 


\begin{tabular}{|c|c|c|c|c|c|c|c|c|c|c|c|c|c|c|}
\hline & \multicolumn{4}{|c|}{ Cobia } & \multicolumn{6}{|c|}{ Grouper } & \multicolumn{4}{|c|}{ Asian seabass } \\
\hline & \multicolumn{2}{|c|}{ North } & \multicolumn{2}{|c|}{ South } & \multicolumn{2}{|c|}{ North } & \multicolumn{4}{|c|}{ Central } & \multicolumn{2}{|c|}{ Central } & \multicolumn{2}{|c|}{ South } \\
\hline & 2010 & 2013 & 2010 & 2013 & 2010 & 2013 & 2010 & 2013 & 2010 & 2013 & 2010 & 2013 & 2010 & 2013 \\
\hline Cage or pond & \multicolumn{4}{|c|}{ cage } & \multicolumn{4}{|c|}{ cage } & \multicolumn{2}{|c|}{ pond } & \multicolumn{2}{|c|}{ pond } & cage & pond \\
\hline$\%$ of households that borrow money & 43 & 55 & 23 & 32 & 57 & 30 & 75 & 26 & 25 & 38 & 25 & 25 & 25 & 16 \\
\hline $\begin{array}{l}\text { Amount of credit borrowed } \\
\text { (USD/crop) }\end{array}$ & 9,300 & 5,600 & 5,700 & 14,000 & 12,000 & 6,700 & 1,100 & 1,500 & 3,900 & 2,200 & 7,700 & 5,000 & 2,600 & 2,200 \\
\hline Average interest rate (\%/month) & 1.1 & 1.7 & 0.8 & 1.0 & 1.0 & 1.9 & 1.3 & 0.7 & 0.9 & 1.2 & 0.9 & 1.2 & 1.3 & 1.3 \\
\hline Credit sources (\% of hhds) & & & & & & & & & & & & & & \\
\hline - Bank & 56 & 67 & 100 & 27 & 38 & 50 & 20 & 71 & 100 & 100 & 100 & 100 & 100 & 67 \\
\hline - Relative & 13 & 33 & 0 & 73 & 10 & 50 & 0 & 0 & 0 & 0 & 0 & 0 & 0 & 33 \\
\hline - Neighbour & 31 & 0 & 0 & 0 & 19 & 0 & 0 & 29 & 0 & 0 & 0 & 0 & 0 & 0 \\
\hline - Other & 0 & 0 & 0 & 0 & 33 & 0 & 80 & 0 & 0 & 0 & 0 & 0 & 0 & 0 \\
\hline
\end{tabular}

Table 11: Credit information.

\begin{tabular}{|c|c|c|c|c|c|c|c|c|c|c|c|c|c|c|}
\hline & \multicolumn{4}{|c|}{ Cobia } & \multicolumn{6}{|c|}{ Grouper } & \multicolumn{4}{|c|}{ Seabass } \\
\hline & \multicolumn{2}{|c|}{ North } & \multicolumn{2}{|c|}{ South } & \multicolumn{2}{|c|}{ North } & \multicolumn{4}{|c|}{ Central } & \multicolumn{2}{|c|}{ Central } & \multicolumn{2}{|c|}{ South } \\
\hline & 2010 & 2013 & 2010 & 2013 & 2010 & 2013 & 2010 & 2013 & 2010 & 2013 & 2010 & 2013 & 2010 & 2013 \\
\hline Cage or pond & \multicolumn{4}{|c|}{ Cage } & \multicolumn{4}{|c|}{ cage } & \multicolumn{2}{|c|}{ pond } & \multicolumn{2}{|c|}{ pond } & cage & pond \\
\hline Total revenue & 6,300 & 9,500 & 54,700 & 34,800 & 20,000 & 5,100 & 7,000 & 10,800 & 20,100 & 74,000 & 15,600 & 35,600 & 10,500 & 10,900 \\
\hline Total costs - with labour costs & 7,300 & 9,800 & 46,500 & 24,600 & 16,700 & 7,800 & 7,700 & 13,500 & 17,400 & 78,000 & 15,700 & 49,200 & 9,100 & 16,500 \\
\hline Total costs/kg production & 5.5 & 3.9 & 3.1 & 3.7 & 9.7 & 12.5 & 8.8 & 12 & 7.9 & 9.8 & 3.0 & 3.3 & 3.0 & 4.1 \\
\hline \multicolumn{15}{|l|}{ Cost structure (\% total costs) } \\
\hline$-\quad$ Seed & 5 & 9 & 6 & 17 & 17 & 17 & 17 & 14 & 17 & 18 & 9 & 6 & 6 & 16 \\
\hline - $\quad$ Feed & 33 & 49 & 72 & 51 & 43 & 24 & 59 & 48 & 58 & 73 & 70 & 82 & 49 & 64 \\
\hline Labour & 56 & 26 & 11 & 17 & 26 & 52 & 13 & 16 & 15 & 3 & 13 & 7 & 28 & 12 \\
\hline - $\quad$ Cage/pond costs & 1 & 1 & 2 & 5 & 1 & 1 & 2 & 18 & 1 & 1 & 2 & 0 & 2 & 1 \\
\hline - $\quad$ Other capital items & 1 & 1 & 1 & 0 & 0 & 1 & 0 & 0 & 3 & 0 & 1 & 0 & 3 & 1 \\
\hline Interest & 0 & 9 & 3 & 5 & 9 & 0 & 2 & 0 & 1 & 0 & 1 & 0 & 7 & 1 \\
\hline Contingency & 5 & 5 & 5 & 5 & 5 & 5 & 5 & 5 & 5 & 5 & 5 & 5 & 5 & 5 \\
\hline Net revenue-with labour costs & $-1,000$ & 0 & 8,200 & 10,200 & 3,300 & $-2,600$ & $-1,000$ & $-2,700$ & 2,600 & $-4,200$ & 0 & $-13,500$ & 1,400 & $-5,600$ \\
\hline $\begin{array}{l}\text { Net revenue-without labour } \\
\text { costs }\end{array}$ & 3,100 & 2,200 & 10,800 & 14,300 & 7,500 & 1,400 & 1,100 & $-1,000$ & 3,800 & $-1,800$ & 1,100 & $-10,300$ & 2,500 & $-3,700$ \\
\hline
\end{tabular}

Table 12: Annual economic statistics (USD/year unless stated otherwise).

the percentage of interest costs in total costs generally decreased. This may indicate an increasing net wealth of farmers allowing them to selffinance their growout operations with reduced dependency on credit.

While total revenue increased for most operations, the costs of production increased by a greater amount such that net revenue decreased for most operations. The farm-gate price of harvested produce decreased for most operations in 2013 relative to 2012, so that farmers could not realise the benefits of increased harvest biomass. The increase in costs and decrease in harvest price resulted in negative profits. The exception to this trend is cobia farming, which realised increase net revenue in both regions over the study period.

So far, the analysis has assumed the household labour is costed at the full value of hired rates. When household labour costs are reduced to zero, the net revenue for northern cobia and northern grouper cobia farmers changes from a negative to a positive value, suggesting that these farmers are making money, but not enough to cover their wages at full market value for their household labour.

\section{Discussion and Conclusion}

Finfish mariculture farming in Vietnam is changing. Many of these drivers for change are economic, to which farmers are making careful practice change decisions. These economic drivers are centred on changes in input and output prices. Most farmers have experienced a reduction in the farm-gate price for their produce over the last three years, in the order of $20-30 \%$. However, most input prices have reduced over the same time frame. Input costs are dominated by feed, labour and seed, all of which have demonstrated an upward trend. This increase in labour prices may be considered a positive driver of change as it indicates a growing employment sector and increasing welfare for households, although in our analysis it increases both the cost of hired labour and the opportunity cost of household labour.

This trend of decreasing output prices and increasing input prices has been termed the cost-price squeeze, or declining terms of trade, and is familiar to the agricultural sector. Results of this study show that mariculture farmers are adapting to the squeeze in a number of ways. The practice change that has had the most significant impact on profit is increasing stocking densities (per unit area), and in the case of cage-culture, also using larger cages (increasing mariculture area). This practice change results in larger numbers of fingerlings stocked. Secondly, the increase in price of fingerlings is related to an increase in fingerling size for cobia and seabass. Survival rates of these fingerlings are mixed. But the net effect of larger sized fingerlings, and larger quantities stocked, is an increase in harvest biomass. Both changes in management practice have led to an increase in biomass harvest, which is proportionally greater the decrease in price, leading to generally higher total revenues received by mariculture farmers.

An exception to this trend is grouper farming in the north, where the price and size of fingerlings stocked has decreased in the three-year 
project period. Perhaps because, on average, fingerlings are smaller, the survival rate also decreased for these farmers. Coupled with a decrease in the number of fish stocked, total revenue dropped. Another exception is cobia farming in the south, where fingerling size increased but mortality also increased and, more importantly, the number of fish stocked also decreased, resulting in a decrease in total revenue. It seems that the number of fish stocked is the dominant driver of total revenue, dominating other drivers such as fingerling size, stocking density and survival rates.

Farmers are also adapting to the cost-price squeeze through riskreducing strategies. On average, grow-out periods have decreased. This has had no impact on the number of crops grown per year, or even on feed costs (the same amount of feed is used over a short-time period with a break before re-stocking). However, it is reducing the risk of disease outbreaks or other events that may increase mortality rates. Average pond area was unchanged over the period, although there was a trend towards a larger number of smaller ponds per household which may be another risk-reducing initiative.

Despite an increase in total revenue for most mariculture operations, the majority of operations experienced a proportionally greater increase in costs, leading to a drop in net revenue. These increases in costs were largely due to increases in feed costs, and to a lesser extent, increases in seed and labour costs. Most farmers are still relying on trash-fish for feed. A minority of cobia farmers use pellets in the nursery stages of growout, and adoption rates of pellets has not increased over the three-year study period. There seems to be reduced incentive to move from trash-fish diets (which are familiar to farmers with perceived lower risk) than pelleted diets, as feed conversion ratios for trash-fish are low and decreasing. However, the greatest level of uncertainty shown by farmers when answering the survey questions was associated with quantities of feed used, so these results should be viewed with a level of uncertainty. Feed conversion ratios for trash-fish are low, so it is understandable that farmers are hesitant to move to an alternative with higher perceived risk, especially while the economic viability of their operations is precarious.

Southern Asian seabass farmers are an exception to this trend. Surveyed farmers had made the practice change from almost exclusively using trash-fish (with a reported feed conversion ratio of 4.0) to almost exclusively using pellets (with a feed conversion ratio of 2.0). However, this reduction in the feed conversion ratio was not enough to ensure the financial viability of these operations. Petersen and Glencross [26] argued that for pellets priced at USD1.30/kg (the current price for southern Asian seabass farmers), the breakeven feed conversion ratio is 1.4. A realistically achievable feed conversion ratio for Asian seabass is 1.2 [27-29]. Using 2013 survey data, the bioeconomic model suggests that a feed conversion ratio of 1.2 would mean the farmers could use $39 \%$ less feed and these farmers could cover their costs as well as earning a wage for their household labour.

These findings highlight some clear implications for aquaculture policy, management and research funding prioritisation. Farmers of cobia, grouper and seabass in Vietnam are price-takers for their inputs and outputs, and must rely on efficiency gains to remain viable if the costprice squeeze continues in these industries. The dominant cost source is feed, so feeding efficiency gains are especially effective for improving economic viability. There is significant room for providing policy and management incentives for encouraging practice change from trashfish to pelleted diets with commensurate minimum feed standards and/or education for the farmers on key quality criteria. This change is likely to lead to fewer problems with parasites, diseases, environmental problems, and more stable water quality. With help through extension services, the feed conversion ratios can be significantly reduced to allow substantial economic benefits.

Survey results show there is strong need to improve farmer perceptions regarding the benefits of pelleted diets. While farmers perceive that fish are adaptable to these diets and that these diets are readily available, many farmers incorrectly perceive these diets to be more costly to use than trash-fish, and none of the surveyed farmers perceived them to have faster growth rates or other associated benefits like shelf stability, consistency of quality and supply, and easier management. Extension and education about the best practice use of pellets and their short and long-term benefits is likely to have significant positive impacts on the long term economic viability and environmental quality of mariculture farming in Vietnam, while protecting wild fish stocks.

Policy, research and extension initiatives that encourage the widespread availability of hatchery produced seedlings of good quality are also likely to allow farmers to increase their number of fingerlings stocked, increase survival rates and therefore increase their harvest biomass. If this can be achieved at low-cost, it is likely to allow the economic viability of the mariculture sector in Vietnam to thrive, while protecting wild fish stocks in the long-term.

\section{Acknowledgement}

The authors would like to sincerely thank the Australian Centre for Internationa Agricultural Research (ACIAR) for funding this project (FIS-2006-141), and all other project collaborators who have contributed to data collection and analysis, and who have provided valued feedback; including Huynh Quang Sang, Ngo Minh Ly, Nguyen Dinh Ky, Nguyen Khac Dat, Nguyen Tien Hoa, Tran Mai Huong, Tran Quoc Binh, Truong Minh Lel and Vu Trong Dai.

\section{References}

1. Food and Agriculture Organization of the United Nations (FAO) (2013) FishstatJ, a tool for fishery statistics analysis.

2. Shaffer RV, Nakamura EL (1989) Synopsis of biological data on the cobia Rachycentron canadum (Pisces: Rachycentridae).

3. Miao S, Jen CC, Huang CT, Hu S (2009) Ecological and economic analysis for cobia Rachycentron canadum commercial cage culture in Taiwan. Aquaculture International 17: 125-141.

4. Chou RL, Su MS, Chen HY (2001) Optimum dietary protein and lipid levels for juvenile cobia (Rachycentron canadum). Aquaculture 193: 81-89.

5. Nguyen QH (2002) Current status of cobia (Rachycentron canadum) culture and seed production in Vietnam. Vietnamese Fisheries Journal 7: 14-16.

6. Chou RL, Her Y, Su MS, Hwang G, Wu YH, et al. (2004) Substituting fish meal with soybean meal in diets of juvenile cobia Rachycentron canadum. Aquaculture 229: 325-333.

7. Wang JT, Liu YJ, Tian LX, Mai KS, Du ZY, et al. (2005) Effect of dietary lipid level on growth performance, lipid deposition, hepatic lipogenesis in juvenile cobia (Rachycentron canadum). Aquaculture 249: 439-447.

8. Nguyen QH, Nhu VC, Do VM, Lauesen P, Pham LH, et al. (2003) Development of cobia (Rachycentron canadum) seed production technique.

9. Nhu VC, Nguyen HQ, Le TL, Tran MT, Sorgeloos P, et al. (2010) Cobia Rachycentron canadum aquaculture in Vietnam: Recent developments and prospects.

10. Huy NQ, Sveier H, Hung BV, Tuan LA, Can NV, et al. (2008) Growth Performance of Cobia, Rachycentron canadum, in sea cages using extruded fish feed or trash fish.

11. Tuan LA (2004) Grouper Culture in Vietnam. Technical Status and Constraints. Special Report, Journal of Sciences and Techniques, Nha Trang University 174-179.

12. Aquaviet (2009) Cage mariculture in Vietnam. 
Citation: Petersen EH, Glencross BD, Tien NV, Tuan LA, Tuan VA, et al. (2015) Recent Changes in the Bioeconomic of Finfish Mariculture in Vietnam. J Aquac Res Development 6: 311. doi:10.4172/2155-9546.1000311

Page 9 of 9

13. Carter CG, Glencross B, Katersky R, Bermudes M (2010) Chapter 14. The Snooks (Family Centropomidae).

14. Glencross B, Wade N, Morton K (2013) Chapter 8. Lates calcarifer nutrition and feeding practices.

15. Sadovy Y, Lau P (2002) Prospects and problems for mariculture in Hong Kong associated with wild-caught seed and feed. Aquaculture Economics and Management 6: 177-190.

16. Petersen EH, Phuong TH (2011) Bioeconomic analysis of improved diets for lobster (Panulirus ornatus) culture in Vietnam. J World Aquacul Soc 42: 1-11.

17. Petersen EH, Chinh DTM, Diu NT, Phuoc VV, Phuong TH, et al. (2013a) Bioeconomics of grouper, Serranidae Epinephelinae, culture in Vietnam. Reviews in Fisheries Science 21: 49-57.

18. Petersen EH, Luan TD, Chinh DTM, Tuan VA, Binh TQ, et al. (2014a) Bioeconomics of cobia, Rachycentron canadum, culture in Vietnam. Aquacul Econom Manag 18: 28-44.

19. Affholder F, Jourdain D, Scopel E, Alary V (2010) Bioeconomic modelling: is there room for seamless interdisciplinarity.

20. Anderson LG, Seijo JC (2010) Bioeconomics of Fisheries Management. Wiley: New York.

21. Clark C (1985) Bioeconomic Modelling and Fisheries Management. New York.
22. Petersen EH, Jones C, Priyambodo B (2014b) Bioeconomics of spiny lobster farming in Indonesia. Asian J Agri Develop 10: 25-39.

23. Petersen EH, Phuong TH, Dung NV, Giang PT, Tuan VA, et al. (2013b) Bioeconomics of mud crab, Scylla paramamosain, culture in Vietnam. Reviews in Aquaculture 5: 1-9.

24. Petersen EH, Phuong TH, Dat NK, Tuan VA, Truc LV (2011) Bioeconomics of Asian seabass, Lates calcarifer, culture in Vietnam.

25. Sinh LX, MacAulay TG, Brennan DC (2006) A Bio-economic Model of a Shrimp Hatchery in the Mekong River Delta of Vietnam. $47^{\text {th }}$ Annual Conference of the Australian Agricultural and Resource Economics Society, Fremantle, Australia.

26. Petersen E, Glencross B (2012) Bioeconomic analysis of improving feed sustainability for marine aquaculture in Vietnam.

27. Glencross BD (2006) Nutritional management of barramundi, Lates calcarifer A review. Aquaculture Nutrition 12: 291-309.

28. Glencross BD (2008) A factorial growth and feed utilisation model for barramundi, Lates calcarifer based on Australian production conditions. Aquaculture Nutrition 14: 360-373.

29. Glencross BD, Bermudes M (2012) Using a bioenergetic modelling approach to understand the implications of heat stress on barramundi (Lates calcarifer) growth, feed utilisation and optimal protein and energy requirements - Options for adapting to climate change? Aquaculture Nutrition 18: 411-422. 